\title{
Self-Assembly of Coordination Polymers: Evidence for Dynamic Exchange between Oligomers in Solution and the Isolation of a Homochiral Decagold(I) Oligomer
}

\author{
Craig A. Wheaton, Michael C. Jennings and Richard J. Puddephatt* \\ Department of Chemistry, University of Western Ontario, London, Canada N6A 5B7.
}

\section{Supporting Materials}

\section{Experimental}

NMR spectra were recorded using a either a Varian Mercury 400 at room temperature or a Varian Inova 400 spectrometer at variable temperature. ${ }^{1} \mathrm{H}$ chemical shifts are reported relative to tetramethylsilane (TMS). ESI mass spectra of solutions in dichloromethane were recorded using a Micromass LCT spectrometer (calibrated with $\mathrm{NaI}$ at concentration $2 \mu \mathrm{g} / \mu \mathrm{l}$ in 50:50 propan-2-ol: water). The complexes $\left[\mathrm{Au}_{2} \mathrm{Cl}_{2}\right.$ ( $\mu$-BINAP)] with either $r a c$ - or $S$-BINAP were prepared as colourless, air stable solids by reacting two equivalents of $\left[\mathrm{AuCl}\left(\mathrm{SMe}_{2}\right)\right]$ with the corresponding diphosphine ligand. ${ }^{1}$ The ${ }^{1} \mathrm{H}$ NMR labeling scheme is given for BINAP.

${ }^{1} H$ NMR labeling scheme for the BINAP ligand

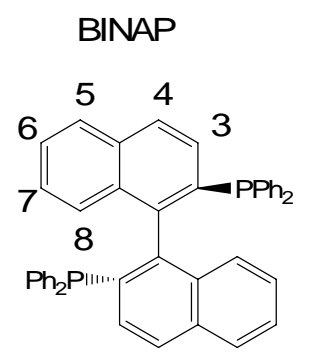

\section{$\left[\mathrm{Au}_{2}\left(\mathrm{CF}_{3} \mathrm{CO}_{2}\right)_{2}(\mu-R, S-B I N A P)\right], 1 \mathrm{a}$}

To a suspension of $\left[\mathrm{AuCl}\left(\mathrm{SMe}_{2}\right)\right](1.00 \mathrm{~g}, 3.39 \mathrm{mmol})$ in acetone $(90 \mathrm{~mL})$ was added a solution of $R, S$-BINAP $(1.06 \mathrm{~g}, 1.70 \mathrm{mmol})$ in acetone. The mixture was stirred for $3 \mathrm{~h}$., yielding $\left[\mathrm{Au}_{2} \mathrm{Cl}_{2}\{\mu-R, S\right.$-BINAP) $]$ as a white precipitate, which was collected by filtration, washed with acetone, diethyl ether and pentane, and dried under vacuum. Yield $1.76 \mathrm{~g}$, $85 \%$.

To a solution of $\left[\mathrm{Au}_{2} \mathrm{Cl}_{2}\{\mu-R, S\right.$-BINAP)] $(0.100 \mathrm{~g}, 0.092 \mathrm{mmol})$ in THF $(10 \mathrm{~mL})$ was added $\mathrm{AgO}_{2} \mathrm{CCF}_{3}(0.041 \mathrm{~g}, 0.186 \mathrm{mmol})$. The mixture was stirred for $30 \mathrm{~min}$., and was filtered through Celite. Solvent was removed, the product was dissolved in a $\mathrm{CH}_{2} \mathrm{Cl}_{2}$ and pentane was added to precipitate the product as a white powder. The product was 
collected by filtration, washed with diethyl ether and pentane, and dried under vacuum. Yield $0.1017 \mathrm{~g}, 89 \%$. NMR in $\mathrm{CD}_{2} \mathrm{Cl}_{2}: \delta\left({ }^{1} \mathrm{H}\right)=8.10$ [d, 2H, 4-H BINAP]; 7.97 [d, 2H, 5-H BINAP]; 7.63 [d, 2H, o-H Ph]; 7.61 [d, 2H, o-H Ph]; 7.57-7.35 [m, 12H, 3-H BINAP + 6-H BINAP + m-H Ph]; $7.29[\mathrm{t}, 4 \mathrm{H}, p-\mathrm{H} \mathrm{Ph}] ; 7.19[\mathrm{~d}, 2 \mathrm{H}, o-\mathrm{H} \mathrm{Ph}] ; 7.17[\mathrm{~d}, 2 \mathrm{H}, o-\mathrm{H}$ $\mathrm{Ph}$ ]; 7.00 [t, 2H, 7-H, BINAP]; 6.72 [d, 2H, 8-H BINAP]; $\delta\left({ }^{31} \mathrm{P}\right)=18.41$ (s); Anal. Calcd for $\mathrm{C}_{48} \mathrm{H}_{32} \mathrm{Au}_{2} \mathrm{~F}_{6} \mathrm{O}_{4} \mathrm{P}_{2}$ : C, 45.99; $\mathrm{H}, 2.57$. Found: $\mathrm{C}, 46.04 ; \mathrm{H}, 2.44 \%$. Crystals were grown by slow diffusion of pentane into a solution of the compound $1 \mathrm{a}$ in $\mathrm{CH}_{2} \mathrm{Cl}_{2}$. Complex $\mathbf{1 b}$ was prepared similarly but using $S$-BINAP.

\section{$\left[\left\{\mathrm{Au}_{2}\{\mu-R, S-\mathrm{BINAP})(\boldsymbol{\mu} \text {-trans-bipyen })\right\}_{\mathrm{n}}\right]\left[\mathrm{CF}_{3} \mathrm{CO}_{2}\right]_{2 \mathrm{n}}, 2 \mathrm{a}$}

To a solution of trans-1,2-bis(4-pyridyl)ethylene $(0.017 \mathrm{~g}, 0.092 \mathrm{mmol})$ in THF $(10 \mathrm{~mL})$ was added a filtered solution of $\left[\mathrm{Au}_{2}\left(\mathrm{CF}_{3} \mathrm{CO}_{2}\right)_{2}(\mu-R, S\right.$-BINAP $\left.)\right] ; \mathbf{1 a}(0.092$ $\mathrm{mmol})$ in THF $(10 \mathrm{~mL})$. The mixture was stirred for $2 \mathrm{~h}$. and the solvent was removed under vacuum. The product was dissolved in $\mathrm{CH}_{2} \mathrm{Cl}_{2}$ and pentane was added to precipitate the product as a white powder, which was washed with pentane, and dried under vacuum. Yield $0.094 \mathrm{~g}, 72 \%$. NMR in $\mathrm{CD}_{2} \mathrm{Cl}_{2}: \delta\left({ }^{1} \mathrm{H}\right)=8.54[\mathrm{~s}, 4 \mathrm{H}, o-\mathrm{H}$ py]; 8.07 [d, 2H, 4-H BINAP]; 7.92 [d, 2H, 5-H BINAP]; 7.64 [d, 2H, $o-\mathrm{H} \mathrm{Ph];} 7.62$ [d, 2H, $o-\mathrm{H}$ $\mathrm{Ph}$ ]; 7.52-7.34 [m, 16H, $m$-H py , $m$-H Ph, 3-H BINAP, 6-H BINAP]; 7.22 [t, 4H, $p-\mathrm{H}$ $\mathrm{Ph}] ; 7.32$ [s, 2H, $\mathrm{C}_{2} \mathrm{H}_{2}$ ]; 7.16 [d, 2H,o-H Ph]; 7.14 [d, 2H,o-H Ph]; $6.96[\mathrm{t}, 2 \mathrm{H}, 7-\mathrm{H}$, BINAP]; 6.67 [d, 2H, 8-H BINAP]; $\delta\left({ }^{31} \mathrm{P}\right)=20.2$ [s]; Anal. Calcd for $\mathrm{C}_{60} \mathrm{H}_{42} \mathrm{Au}_{2} \mathrm{P}_{2} \mathrm{~N}_{2} \mathrm{O}_{4} \mathrm{~F}_{6}$ : C, 50.57; H, 2.97; N, 1.97. Found: $\mathrm{C}, 50.22 ; \mathrm{H}, 2.81 ; \mathrm{N}, 2.09 \%$. Single crystals of $2 \cdot 2.65 \mathrm{CH}_{2} \mathrm{Cl}_{2}$ were grown by slow diffusion of pentane into a solution of complex 2 in dichloromethane.

Complex $\mathbf{2 b}$ was prepared similarly using $S$-BINAP and was crystallized from acetone/pentane.

\section{$\left[\mathrm{Au}_{10}(\mu-S-B I N A P)_{5}(\mu \text {-bipyen })_{4}(\text { bipyen })_{2}\right]\left[\mathrm{CF}_{3} \mathrm{CO}_{2}\right]_{10}, 3$}

This was prepared similarly from trans-1,2-bis(4-pyridyl)ethylene $(0.017 \mathrm{~g}, 0.092$ mmol) and $\left[\mathrm{Au}_{2}\left(\mathrm{CF}_{3} \mathrm{CO}_{2}\right)_{2}(\mu-S\right.$-BINAP $\left.)\right], 1 \mathbf{b}(0.092 \mathrm{mmol})$. Yield $0.090 \mathrm{~g}, 68 \%$. NMR in $\mathrm{CD}_{2} \mathrm{Cl}_{2}: \delta\left({ }^{1} \mathrm{H}\right)=8.55$ [s, 24H, $o$-H py]; 8.11 [d, 10H, 4-H BINAP]; 7.95 [d, 10H, 5-H BINAP]; 7.68 [d, 10H, $o-\mathrm{H} \mathrm{Ph}] ; 7.66[\mathrm{~d}, 10 \mathrm{H}, o-\mathrm{H} \mathrm{Ph}] ; 7.58-7.38[\mathrm{~m}, 84 \mathrm{H}, m-\mathrm{H}$ py, $m-\mathrm{H}$ $\mathrm{Ph}$, 3-H BINAP, 6-H BINAP]; 7.37 [s, 12H, $\mathrm{C}_{2} \mathrm{H}_{2}$ ]; 7.23 [t, 20H, $p$-H Ph]; 7.19 [d, 10H, $o-\mathrm{H} \mathrm{Ph}$ ]; 7.17 [d, 10H, $o-\mathrm{H} \mathrm{Ph}$ ]; 6.99 [t, 10H, 7-H, BINAP]; 6.70 [d, 10H, 8-H BINAP]; $\delta\left({ }^{31} \mathrm{P}\right)=23.3$ [s]. Anal. Calcd. for $\mathrm{C}_{312} \mathrm{H}_{220} \mathrm{Au}_{10} \mathrm{~F}_{30} \mathrm{P}_{10} \mathrm{~N}_{12} \mathrm{O}_{20}: \mathrm{C}, 51.29 ; \mathrm{H}, 3.04 ; \mathrm{N}, 2.30$. Found: C, 50.79; H, 2.93; N, $2.18 \%$. Single crystals of $3 \cdot 7.5 \mathrm{CH}_{2} \mathrm{Cl}_{2}$ were grown by slow diffusion of pentane into a solution of complex $\mathbf{3}$ in dichloromethane.

The ${ }^{31} \mathrm{P}$ NMR spectra of 3 in $\mathrm{CD} 2 \mathrm{Cl} 2$ at (a) room temperature and (b) $-60{ }^{\circ} \mathrm{C}$ are shown below. 


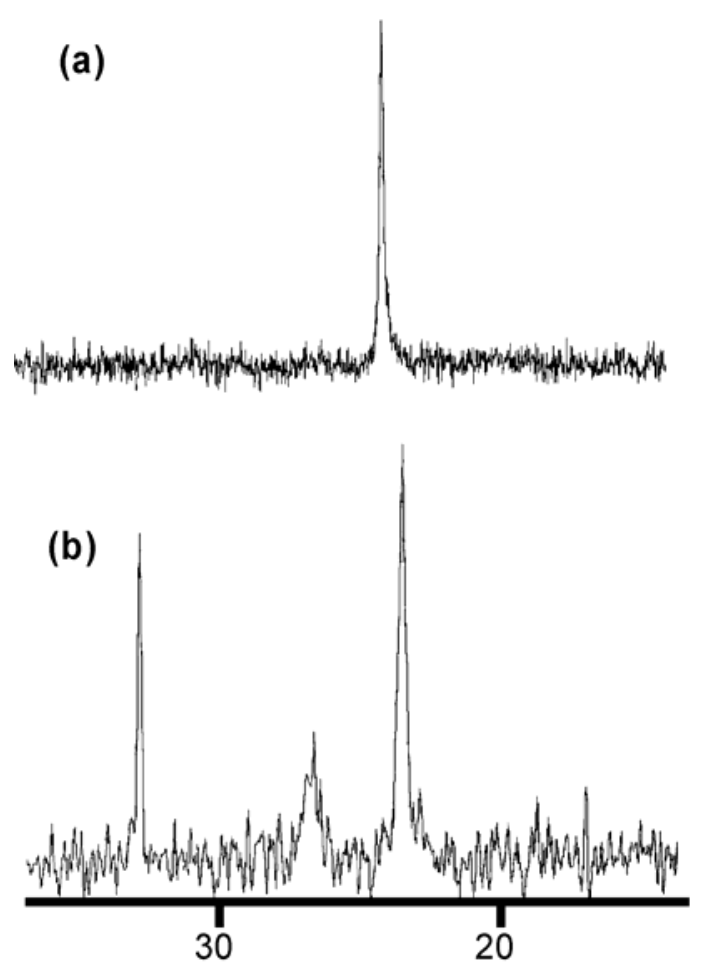

\section{X-ray Structure Determinations}

Crystals were mounted on glass fibers. Data were collected at $150 \mathrm{~K}$ using a Nonius Kappa-CCD area detector diffractometer with COLLECT (Nonius B.V., 1998). Crystal cell refinement and data reduction were carried out using HKL2000 DENZOSMN (Otwinowski \& Minor, 1997). The absorption correction was applied using SCALEPACK. The SHELXTL V6.1 (Sheldrick, G.M., 2001) suite of programs was used to solve the structure by direct methods for $\mathbf{2}$ and by Patterson methods for $\mathbf{3}$. Subsequent difference Fourier syntheses allowed the remaining atoms to be located. Data are listed in the Table and the associated cif files.

The complex 3 formed crystals which diffracted weakly, complicating the refinement, and so some details of the structure determination are described. Reflection data were consistent with a trigonal system; $P 3_{2} 21$. (The structure was also solved in the space group $P 3_{2}$ which resulted in two identical molecules being present in the asymmetric unit and significantly higher $\mathrm{R}$ values at convergence. Furthermore, a check on this solution using ADDSYM of the PLATON suite of programs suggested the space group $P 3_{2} 21$ ). The structure was solved using the automated Patterson routine of the SHELX-TL V6.1 program package. Subsequent difference Fourier syntheses allowed the remaining atoms to be located. Geometric restraints were necessary to refine the poorly defined light atoms $(\mathrm{C}, \mathrm{N})$ in the structure solution. Only the gold atoms were refined with anisotropic thermal displacement parameters. The large voids in the lattice were filled with the $\mathrm{CF}_{3} \mathrm{COO}^{-}$anions and dichloromethane solvent molecules; all of these molecules and ions were disordered and most could not be modeled. Thus, the 
SQUEEZE procedure of the PLATON suite of programs was used to account for the anion and solvent electron density. A total of 5248 electrons were removed in a volume of $27689 \AA$ (48.2\% of the unit cell). ${ }^{2} 3360$ electrons are assigned to the $60 \mathrm{CF}_{3} \mathrm{COO}^{-}$ anions, with the remaining 1888 electrons assigned to 45 molecules of dichloromethane. (This equates to $10 \mathrm{CF}_{3} \mathrm{COO}^{-}$anions and $7.5 \mathrm{CH}_{2} \mathrm{Cl}_{2}$ per asymmetric unit). The SQUEEZE processed data were used for all subsequent refinement cycles. The hydrogen atoms were calculated geometrically and were riding on their respective carbon atoms.

\section{References}

1. Brandys, M.-C.; Jennings, M.C.; Puddephatt, R.J. J. Chem. Soc. Dalton Trans. 2000, 4601.

2. Spek, A.L. Acta Crystallogr., Sect. A, 1990, 46, C46. 
Table: Crystal and Refinement Data.

\begin{tabular}{|c|c|c|c|}
\hline & $\mathbf{2 a} \cdot 2.65 \mathrm{CH}_{2} \mathrm{Cl}_{2}$ & $\mathbf{2 b} \cdot 3$ acetone & $\mathbf{3} \cdot 7.5 \mathrm{CH}_{2} \mathrm{Cl}_{2}$ \\
\hline Formula & $\mathrm{C}_{62.65} \mathrm{H}_{47.3} \mathrm{Au}_{2} \mathrm{Cl}_{5.3} \mathrm{~F}_{6} \mathrm{~N}_{2} \mathrm{O}_{4} \mathrm{P}_{2}$ & $\mathrm{C}_{66} \mathrm{H}_{56} \mathrm{Au}_{2} \mathrm{~F}_{6} \mathrm{~N}_{2} \mathrm{O}_{7} \mathrm{P}_{2}$ & $\mathrm{C}_{319.5} \mathrm{H}_{235} \mathrm{Au}_{10} \mathrm{Cl}_{15} \mathrm{~F}_{30} \mathrm{~N}_{12} \mathrm{O}_{20} \mathrm{P}_{10}$ \\
\hline fw & 1649.88 & 1559.00 & 7943.31 \\
\hline$T / \mathrm{K}$ & $150(2)$ & $150(2)$ & $150(2)$ \\
\hline$\lambda / \AA$ & 0.71073 & 0.71073 & 0.71073 \\
\hline Cryst. system & monoclinic & orthorhombic & trigonal \\
\hline Space group & $\mathrm{P} 2_{1} / \mathrm{c}$ & $\mathrm{P} 2{ }_{1}{ }_{1} 2_{1}$ & $\mathrm{P} 3{ }_{2} 21$ \\
\hline$a[\AA]$ & $16.9939(4)$ & $14.9319(3)$ & $36.405(1)$ \\
\hline$b[\AA]$ & $18.6105(4)$ & $16.5595(3)$ & $36.405(1)$ \\
\hline$c[\AA]$ & $20.5133(4)$ & $27.0293(5)$ & $49.917(2)$ \\
\hline$\alpha\left[^{\circ}\right]$ & 90 & 90 & 90 \\
\hline$\beta\left[^{\mathrm{o}}\right]$ & $106.347(1)$ & 90 & 90 \\
\hline$\gamma\left[{ }^{\mathrm{o}}\right]$ & 90 & 90 & 120 \\
\hline$V\left[\AA^{3}\right]$ & $6225.4(2)$ & $6683.4(2)$ & $57294(2)$ \\
\hline$Z$ & 4 & 4 & 6 \\
\hline $\mathrm{d}$ (calc.) $/ \mathrm{Mg} \mathrm{m}^{-3}$ & 1.760 & 1.549 & 1.381 \\
\hline$\mu / \mathrm{mm}^{-1}$ & 5.053 & 4.500 & 3.904 \\
\hline Abs. corr. & multiscan & multiscan & multiscan \\
\hline$F(000)$ & 3205 & 3056 & 23166 \\
\hline reflections & 60239 & 11779 & 297432 \\
\hline unique reflections & 10970 & 11779 & 18116 \\
\hline Data/restr./param. & 10970 / 18 / 682 & $11779 / 1586 / 820$ & $18116 / 836 / 1155$ \\
\hline$R 1, \mathrm{w} R 2[\mathrm{I}>2 \sigma(\mathrm{I})]$ & $0.052,0.133$ & $0.072,0.175$ & $0.081,0.211$ \\
\hline Abs. struct. param. & & $0.135(15)$ & $0.095(17)$ \\
\hline
\end{tabular}

